\title{
THE EFFECT OF TAX TREATY ON FOREIGN DIRECT INVESTMENT IN INDONESIA
}

\author{
Hutomo Nurman Satrio, Nur Indah Lestari*) \\ Department of Customs and Excises Polytechnic of State Finance STAN \\ *Email: indah@pknstan.ac.id
}

\begin{abstract}
This paper examines the effect of tax treaty, so called Perjanjian Penghindaran Pajak Berganda (P3B), on foreign direct investment inflow to Indonesia in short, middle and long term. From 67 countries that have P3B with Indonesia, we work only with 51 countries because of no longer P3B exist or lack of completed data. Using panel data set of 51 countries from 2000 to 2015 and applying fixed effect model, we find that $P 3 B$ has insignificant relationship to foreign direct investment inflows in short term. However, tax treaty, both in middle and long term, have a positive relationship on Indonesia's foreign direct investment inflow with $10 \%$ and $1 \%$ significant level, respectively. Furthermore, the data show that in all term there are RpO foreign direct investment inflow from corresponding countries, which are $58 \%$ countries in short terms, $61 \%$ in middle term, and $64 \%$ in long term. From all those countries that has no investment agreement, majority of them are lower middle income countries. So, Government should evaluate tax treaty that are present and consider more about macroeconomics factor from partner country before signing an agreement.
\end{abstract}

Keywords: tax treaty, foreign direct investment, $P 3 B$, panel data.

\begin{abstract}
Abstrak
Makalah ini mengkaji pengaruh perjanjian pajak, yang disebut sebagai Perjanjian Penghindaran Pajak Berganda (P3B), mengenai arus masuk investasi langsung asing ke Indonesia dalam jangka pendek, menengah dan panjang. Dari 67 negara yang memiliki P3B dengan Indonesia, kami hanya bekerja dengan 51 negara karena tidak ada P3B atau kurangnya data yang lengkap. Dengan menggunakan kumpulan data panel dari 51 negara dari tahun 2000 hingga 2015 dan menerapkan model efek tetap, kami menemukan bahwa P3B memiliki hubungan tidak signifikan dengan arus masuk investasi langsung asing dalam jangka pendek. Namun, perjanjian pajak, baik dalam jangka menengah dan panjang, memiliki hubungan positif pada arus masuk investasi langsung asing dengan masingmasing $10 \%$ dan $1 \%$ tingkat signifikan. Selanjutnya, data menunjukkan bahwa
\end{abstract}


dalam semua jangka waktu ada arus masuk investasi langsung asing sebesar Rp0 dari negara-negara yang bersesuaian, yaitu 58\% negara dalam jangka pendek, $61 \%$ dalam jangka menengah, dan $64 \%$ dalam jangka panjang. Dari semua negara yang tidak memiliki perjanjian investasi, mayoritas dari mereka adalah negara berpenghasilan menengah ke bawah. Jadi, Pemerintah harus mengevaluasi perjanjian pajak yang ada dan mempertimbangkan lebih lanjut tentang faktor makroekonomi dari negara mitra sebelum menandatangani perjanjian.

Kata kunci: perjanjian pajak, investasi langsung asing, P3B, data panel.

\section{INTRODUCTION}

As one of the developing countries, Indonesia succeeded in obtaining FDI with a proportion of 68 percent of the total realized investment over the last five years. The growth of FDI inflows in Indonesia from 2010 to 2015 has increased significantly, from 16,214.8 million US dollars to 29,275.9 million US dollars. However, the net inflows of FDI which is the net amount of the investment inflows minus the outward divestment of Indonesia, the value of FDI net inflows Indonesia is still fluctuating as shown in Figure 1.

This fluctuating FDI net inflow is considered to be increase all the time. Applying tax treaty is one way to have higher FDI inflow (Tambunan, 2016). In order to minimize this effect, Government had applied tax treaty, so called double tax agreement "Perjanjian Pajak Berganda" (P3B) with some other countries since 1990.

The implementation of P3B between Indonesia and partner countries has a different impact on Indonesia's FDI Inflows. FDI inflows increase after the signing of P3B between Indonesia and some countries such as Singapore, Malaysia, England, Germany and Netherlands (Appendix 1). This is consistent with either et al. (2011) and Hines (1998) concluded that government policies such as P3B and tax incentives to investors have a significant impact on FDI inflows to host country.

However, there are countries that have had P3B with Indonesia for more than 5 years and had shown zero FDI inflows' value, such as Pakistan and Poland (Appendix 1). This is not in line with the results of Ohno (2010) explained that the tax treaty has a positive and significant effect on FDI inflows to Japan in the long term that is within more than 4 years after the signing of tax treaty. 


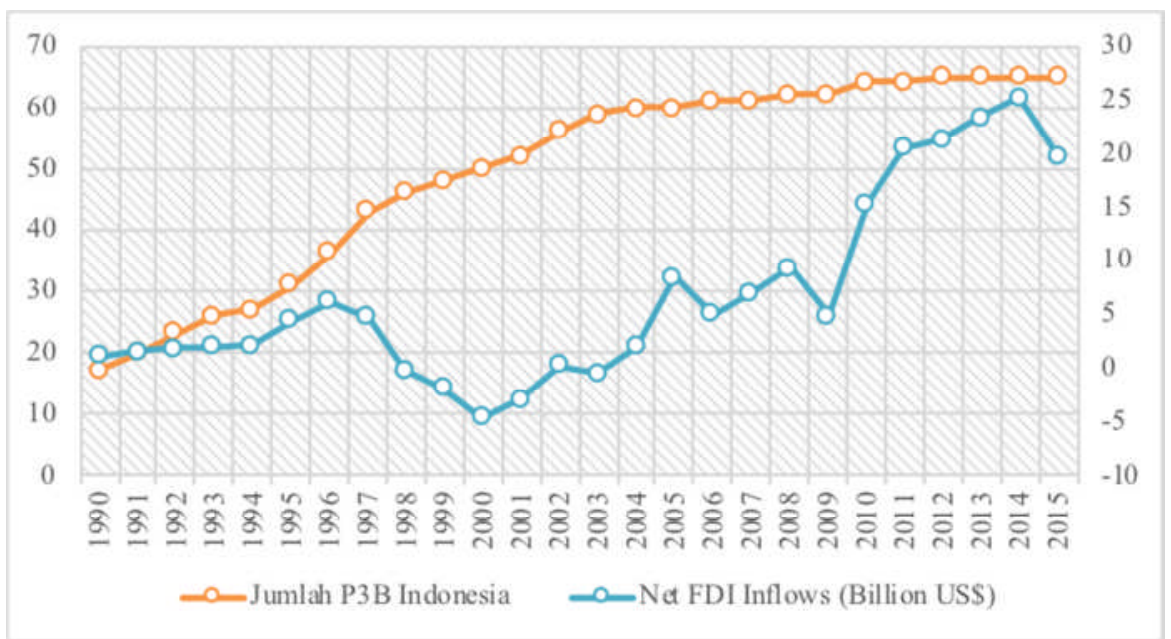

Figure 1: Total Number of Tax Treaties (P3B) and FDI Net Inflows in Indonesia

Source: Self proceed from World Bank data

Moreover, the data show that Poland invested FDI to Indonesia only on 2007 after 15 years of signing P3B. Having this experience doesn't urge government to stop an agreement but deals with other countries with another P3b instead. Since 2000 until 2010, some new agreements also provide no additional FDI inflows to Indonesia after more than 5 years, as shown in Appendix 2. Therefore, the government should evaluate first the pre-existing P3B as there are some P3B that do not provide benefits for Indonesia (Prastowo in Apriliani, 2014).

Based on background, this research is conducted to show the effect of P3B on FDI inflows to Indonesia in the short, medium and long term. This research also provides some advices for the government in establishing policies to encourage FDI Inflows to Indonesia.

\section{LITERATURE REVIEW}

Theoretical studies show that there are many factors for FDI inflows to a country. Nowadays, many bilateral tax treaties have also made for various advantages. This relationship between tax treaty and FDI has been widely discussed among scholars. Some researches concern about how long the agreement was exist as the determinant of FDI. One of them explain by Bhasin and Manocha (2016), Murthy and Bhasin (2015), Nurhidayat (2012), and Ohno (2010). All researchers used panel data, but applied different methods, such as fixed effect approach (Murthy and Bhasin, 2015 and Nurhidayat, 2012), two steps generalized method of moments (GMM) (Bhasin and Manocha, 2016), dynamic panel estimation (Ohno, 2010), and gravity equation (Digumber et. al., 2017). 
Most of the independent variables used by them in addition to FDI are growth domestic product (GDP) home and host country, trade openness, financial openness and population growth. Bhasin and Manocha (2016) concludes that the total GDP of both countries, financial transparency, population growth and the existence of bilateral investment agreements between countries (BIT) influenced the Indian FDI flow, but other variables such as distance, language, colonialism, political constraint have an insignificant relationship. Murti and Bhasin (2015) show that the GDP home country, GDP hosts country, GDP per capita, financial openness and population growth are the main factors driving FDI in India.

In term of tax treaty, the results of Ohno's research (2010) showed that the emergence of tax treaties has a significant effect on long-term investment scale. Similarly, Nurhidayat (2012) explained that the existence of P3B, both new agreements and revisions of $\mathrm{P} 3 \mathrm{~B}$ will have a negative impact in the short term but turn positive in the medium and long term.

\subsection{Model}

Based on the results of previous research, independent variables use Ohno (2010) research model by dividing P3B period into short, medium and long term. The control variables used by Murthy and Bhasin (2015) research indicate that the GDP ratio of home country and host country, financial openness and population growth are the main factors driving FDI. In addition, other control variables such as trade openness are from Bhasin and Manocha (2016) research and the exchange rate of partner countries against US dollar is based on Ohno (2010). Therefore, the equation is as follows:

$$
\begin{gathered}
\text { Ln }(1+\text { FDIijt })=\alpha+\beta_{1} D T T 1_{i j t}+\beta_{2} \text { DTT2 }_{i j t}+\beta_{3} \text { DTT3 }_{i j t}+\beta_{4} L n G D P R_{i j t}+\beta_{5} L n \\
E X C_{i t}+\beta_{6} \text { LnTOPEN }_{i t}+\beta_{7} \text { FOPEN }_{i t}+\beta_{8} P O P G_{i t}+\varepsilon_{i j t}
\end{gathered}
$$

Where:

$F D I_{i j t}=$ FDI Inflows from home country $i$ in year $t$ to host country, Indonesia $D T T 1_{i j t}=$ Dummy variable short term tax treaty, where 1 for period when P3B or its revised is applied and 0 otherwise.

$D T T 2_{i j t}=$ Dummy variable of middle term tax treaty, where 1 for period that have applied $\mathrm{P} 3 \mathrm{~B}$ or its revised from one to four years, while 0 otherwise.

$D T T 3_{i j t}=$ Dummy variable of long term tax treaty, where 1 for period that $\mathrm{P} 3 \mathrm{~B}$ or its revised have been applied for more than four years.

$G D P R_{i j t} \quad=$ GDP ratio of home country to host country

$E X C_{i t}=$ Exchange rate of partner countries against US dollar

$T_{O P E N_{i i}}=$ Trade openness

FOPEN $_{i t} \quad=$ Financial openness

$P O P G_{i t}=$ Population growth in partner country

Ln = Natural logarithm

$\varepsilon \quad=$ Error term

$\alpha \quad=$ Constant 


\section{DATA AND RESEARCH TECHNIQUE ANALISYS}

\subsection{Data}

Indonesia has tax treaty, so called P3B, with 67 countries for the last 16 years. However, Mauritius is excluded because of no longer P3B exist and 15 countries cannot be used due to insufficient data. Consequently, this paper uses 51 countries since 2000 to 2015 . Tabel 1 provides more detail about the data.

Tabel 1 Statistic Descriptive Analysis

\begin{tabular}{|c|c|c|c|c|c|}
\hline Variabel & Mean & Median & Maximum & Minimum & Std. Dev. \\
\hline FDI & $504.759,100$ & 494,200 & $170.106 .626,900$ & 0,000 & $6.497 .592,000$ \\
\hline DTT1 & 0,015 & 0,000 & 1,000 & 0,000 & 0,120 \\
\hline DTT2 & 0,087 & 0,000 & 1,000 & 0,000 & 0,282 \\
\hline DTT3 & 0,839 & 1,000 & 1,000 & 0,000 & 0,367 \\
\hline GDPR & 2,161 & 0,551 & 60,868 & 0,001 & 5,529 \\
\hline EXC & 262,613 & 4,220 & $29.011,490$ & 0,269 & $1.859,328$ \\
\hline TOPEN & 92,747 & 74,966 & 442,620 & 19,798 & 68,404 \\
\hline FOPEN & 7,632 & 3,912 & 158,505 & $-35,090$ & 14,294 \\
\hline POPG & 1,079 & 0,760 & 14,237 & $-2,851$ & 1,611 \\
\hline
\end{tabular}

Source: Self proceed

\subsection{Panel Regression Analysis}

There are three model of panel data, which are Common Effect, Fixed Effect and Random Effect (Nachrowi and Usman, 2006). This paper operated Chow test, Lagrange Multiplier test and Hausman test to obtain the best panel regression. Before running the panel regression, we also analyzed all the assumptions needed to have the best linear unbiased estimator (BLUE) (Wooldridge, 2004).

\section{RESULT AND DISCUSSION}

\subsection{Panel Regression Model Test}

\subsubsection{Chow Test}

Chow test is done to decide whether the panel data fit for common ordinary least square (OLS) model or fixed effect model (FEM). The result shows that this research will be better to use FEM, Figure 2 . 
Redundant Fixed Effects Tests

Equation: FIXEDWEIGHTED

Test cross-section fixed effects

\begin{tabular}{lccc}
\hline \hline Effects Test & Statistic & d.f. & Prob. \\
\hline \hline Cross-section F & 66.207912 & $(50,757)$ & 0.0000 \\
\hline
\end{tabular}

Figure 2: Chow Test Result

Source: Self Proceed

\subsubsection{Hausman Test}

Hausman test is done to choose between FEM and random effect model (REM). This result shows that FEM is better than REM in this model, Figure 3.

Correlated Random Effects - Hausman Test
Equation: RANDOM
Test cross-section random effects
\begin{tabular}{lrrrr}
\hline Test Summary & Chi-Sq. Statistic & Chi-Sq. d.f. & Prob. \\
\hline \hline Cross-section random & 92.275114 & 8 & 0.0000 \\
\hline
\end{tabular}

Figure 3: Hausman Test Result

Source: Self Proceed

Based on these two tests, we apply FEM in the model. This approach is similar with previous research by Murthy and Bhasin (2015) and Nurhidayat (2012).

\subsection{Fixed Effect Model Result}

Having all the Classics Linear Regression Model assumption are fulfilled, by applying feasible general least square (FGLS) for fixing heteroscedastic problem, Figure 4 and show the result of Fixed Effect Model.

\begin{tabular}{llll}
\hline \hline \multicolumn{4}{c}{ Weighted Statistics } \\
\hline \hline R-squared & 0.947265 & Mean dependent var & 8.884657 \\
Adjusted R-squared & 0.943224 & S.D. dependent var & 10.34722 \\
S.E. of regression & 2.362109 & Sum squared resid & 4223.727 \\
F-statistic & 234.4435 & Durbin-Watson stat & 1.529730 \\
Prob(F-statistic) & 0.000000 & & \\
\hline \hline
\end{tabular}

Figure 4: Fixed Effect Model Result Source: Self Proceed

Adjusted $\mathrm{R}^{2}$ of this research shows that the model explains $94 \%$ of FDI. Furthermore, all independent variables simultaneously affect FDI. However, individually, some variables do not significantly stimulate FDI, as shown in Table 2 .

Table 2: Fixed Effect Model Result

\begin{tabular}{|c|c|c|c|c|}
\hline Variable & Coefficient & Std. Error & t-Statistic & Prob. \\
\hline DTT1 & 0,554499 & 0,500384 & 1,108146 & 0,500384 \\
\hline DTT2 $*$ & 0,590736 & 0,318676 & 1,853718 & 0,0642 \\
\hline DTT3 $* * *$ & 1,392023 & 0,338688 & 4,110044 & 0,0000 \\
\hline Ln GDPR $* * *$ & $-1,203273$ & 0,199792 & $-6,022626$ & 0,0000 \\
\hline
\end{tabular}




\begin{tabular}{|c|c|c|c|c|}
\hline Ln EXC & $-0,220861$ & 0,183785 & $-1,201738$ & 0,2298 \\
\hline Ln TOPEN & $-1,794034$ & 2,100998 & $-0,853896$ & 0,3934 \\
\hline FOPEN & 0,004160 & 0,005681 & 0,732347 & 0,4642 \\
\hline POPG ** & $-0,160171$ & 0,076338 & $-2,098194$ & 0,0362 \\
\hline $\mathrm{C}^{* * *}$ & 5,693984 & 1,353865 & 4,205725 & 0,0000 \\
\hline
\end{tabular}

Note: significant level in $\left.\left.{ }^{*}\right) 10 \%,{ }^{* *}\right) 5 \%$ and $\left.{ }^{* * *}\right) 1 \%$

Source: Self Proceed

Based on Table 2, the age of tax treaty creates FDI inflows by $10 \%$ significant level in middle term and $1 \%$ significant level in long term. However, in the short term, P3B brings no significant effect to FDI inflow.

Another control variable gives different effect to FDI as well as its significant level. GDP Ratio of home to host country (GDPR) and population growth (POPG) have significant negative impact toward FDI in $1 \%$ and $5 \%$, respectively. In addition, exchange rate (EXC) and trade openness (TOPEN) are also having negative effect, but they are insignificantly causing FDI inflows. Lastly, financial openness (FOPEN) has positive effect toward FDI but insignificant.

Furthermore, we get the equation as follow.

$$
\begin{gathered}
\text { Ln }(1+F D \text { Iijt })=5,694+0,554 D_{\text {DTT1 }}+0,591 \text { DTT2 }_{i j t}+1,392 \text { DTT3 }_{i j t}-1,203 \\
\text { Ln GDPR } \\
i j t
\end{gathered}
$$

$$
+\varepsilon_{i j t}
$$

The equation indicates that having $\mathrm{P} 3 \mathrm{~B}$ in the short term, middle term and longterm increase FDI inflow as much as 0,$554 ; 0,591 ; 1,392$, respectively, compare to no P3B existing. Similarly, additional financial openness also gains 0,004 FDI inflows.

However, $1 \%$ additional GDP ratio, exchange rate and trade openness decrease $1,203 \%, 0,221 \%$, and 1,794\% FDI inflow, separately.

\subsection{Short Term Analysis}

Result shows that P3B in short term provides no significant FDI inflow to Indonesia. The result goes along with Ohno (2010) that in the short-term tax treaty is not directly affecting host country FDI inflow. Research data, from 2000 to 2015, supports that there are both new and revise P3B with 12 countries. However, the FDI inflows from those countries are differ as shown in Figure 5. 


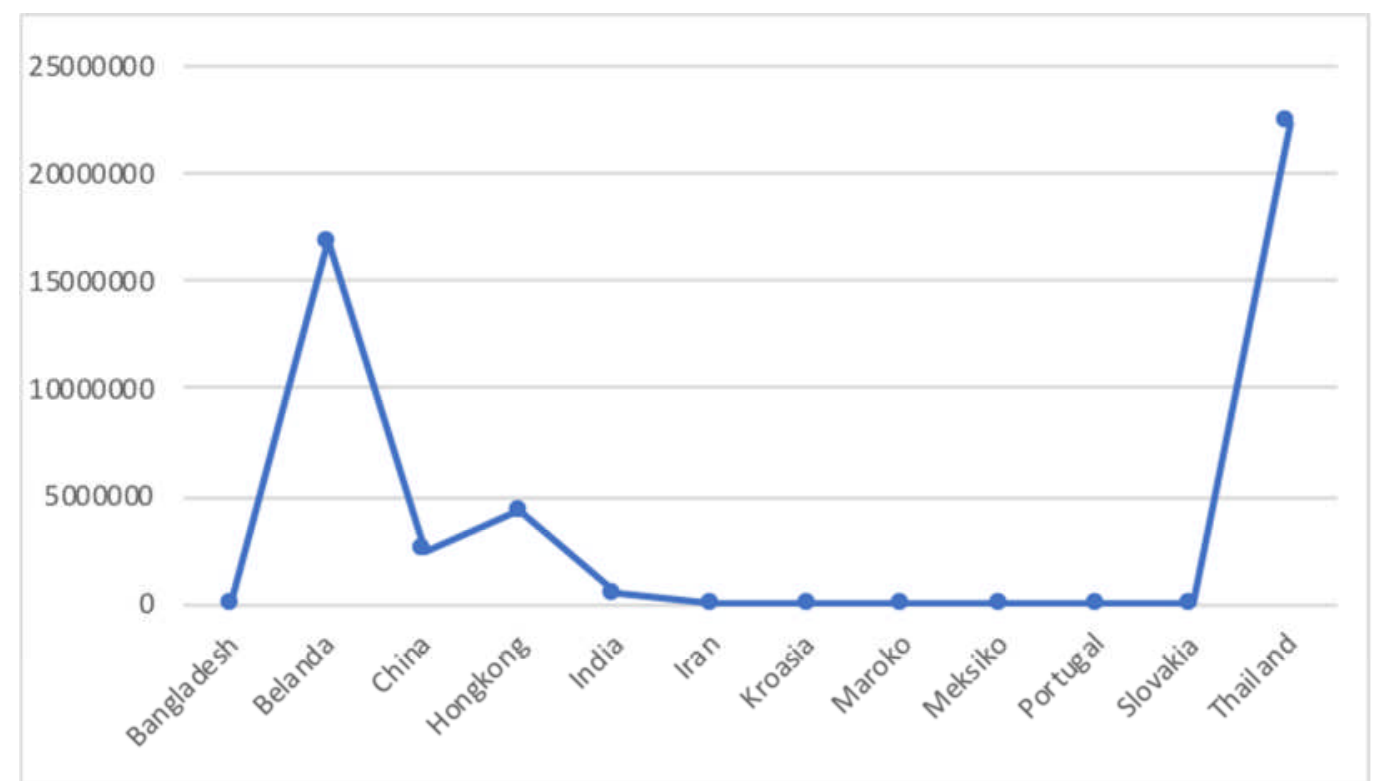

Figure 5: Total of FDI inflow to Indonesia from 2000 to 2015 Source: Self Proceed from world bank data

From 12 countries, there are only 5 countries that have FDI inflow to Indonesia by the time the P3B was signed. They are Netherland and Hong Kong, high income country, China and Thailand, which are upper middle-income country, and India as lower middle-income country.

However, from 7 other countries, Croatia, Morocco, and Portugal have zero FDI inflows to Indonesia since the beginning of the P3B until 2008. The rest, Bangladesh, Iran, Mexico, and Slovakia has some FDI inflow but only in some years.

Therefore, government should pay more attention to all relating countries since the beginning of agreement. In order to have better P3B impacts for the following years.

\subsection{Middle Term Analysis}

Result shows that P3B in middle term significantly stimulate FDI inflow to Indonesia. Similarly, Murthy and Bhasin (2015) conclude that the age of P3B brings significant effect to FDI inflow. Based on research data year 2000 to 2015, there are 23 countries that have age of P3B from 1 to 4 years. There are 14 countries out of 23 who have zero FDI inflow in middle term.

Conversely, 9 countries with non-zero FDI inflow are South Africa, America, Netherland, China, Hong Kong, India, Canada, Thailand, and Jordan. From those 9 countries, India is the only one country that is low middle-income country.

\subsection{Long Term Analysis}

Finding for long term, P3B provide significant FDI inflow to Indonesia. There are 50 countries with long term $\mathrm{P} 3 \mathrm{~B}$ contract in the research data. This shows that 
tax treaty has been done with many countries even before year 2000. Still, 32 out of 50 countries have zero FDI inflow in the long term. Most of those countries are lower middle-income country. Hence, government should pay more attention on those lower middle-income countries that have no investment agreement. Also, governments are supposed to analyze the existing tax treaty agreement with those countries.

P3B offer not only increasing FDI inflow but also reducing tax avoidance as well as tax evasion. Furthermore, having tax treaty agreement will contribute to solve international tax problem along with collaborate international economic development (Nurhidayat, 2012).

This result goes with many previous research, such as Murthy and Bhasin (2015) and Ohno (2010). The age of tax treaty matters almost in all research, the longer an agreement exist the more advantage gain by host country. In short, P3B as tax treaty between Indonesia and partner country will foster FDI inflow in long term. For that reason, government had better to evaluate all the P3B existing with another country who gain no FDI inflow, especially in the long term.

\subsection{Control Variable Analysis}

First, GDP ratio of home to host country gives negative effect to FDI inflows, significantly. Increasing GDP ratio will hold up FDI inflow, because if host country has bigger market than home country, then investor will be not attracted to invest.

Second, trade openness brings no significant effect to FDI inflow. Moreover, the negative sign presents that country with more export and import activity will choose domestic investment rather than foreign investment.

Third, host country foreign exchange rate toward dollar has no significant effect to FDI inflow. The negative sign also shows that if there is an appreciation in foreign exchange rate, then the country gains more power to facilitate raw materials needed.

Fourth, financial openness also has no significant effect to FDI inflow. However, the positive sign means that the more open host country provide more FDI inflow to home country.

Lastly, population growths of in partner country prepare more labor growth and consumption rate in its country. Therefore, host country market will be bigger and demand for domestic investment. This condition explains the positive sign that this paper earn.

Finally, beside the age of $\mathrm{P} 3 \mathrm{~B}$, government should care more in macro assumption in partner country while doing a tax treaty, P3B. Also, government need to know openness in host country both trade and financial. 


\section{CONCLUSION}

Based on the results, the analysis and discussion as described in the previous chapter, it can be concluded that partner countries which have P3B with Indonesia in the short term did not significantly affect FDI inflows to Indonesia. However, partner countries which have P3B with Indonesia in the medium and long term have a significant and positive impact on FDI inflows to Indonesia.

In line with the result, we recommend Directorate General of Tax (DGT) should evaluate P3B with some partners countries that have zero FDI flows within a few years or tend to be negative. In order to evaluate the tax treaty, DGT should be able to work with other Ministries and Institutions such as the Ministry of Foreign Affairs, the Ministry of Commerce and the Investment Coordinating Board. In addition, in conducting the signing of new P3B or its revise with partner countries, DGT should consider the macroeconomic factors of partner countries. For future research, this paper only uses 16 years observation, so if it is possible to add more years to have bigger investment visualization. In term of exchange rate, this paper work with dollar, but it's better to use home country currency.

\section{REFERENCES}

Ahmadi, W. (2007), Perjanjian Penghindaran Pajak Berganda (Tax Treaty) dalam Kaitannya dengan Transaksi Internasional. Jurnal Hukum Pro Justitia. Oktober 2007. Volume 25 No. 4.

Apriliyani, Jane. (2014), Tak akan ada lagi perjanjian tax treaty baru. http://m.kontan.co.id/news/tak-akan-ada-lagi-perjanjian-tax-treaty-baru.

Accessed: September 10 ${ }^{\text {th }}, 2017$.

Bhasin, N. dan Manocha, R. (2016), Do Bilateral Investment Treaties Promote FDI Inflows? Evidence from India. Vikalpa, 41(4), pp.275-287.

Eicher, T., Helfman, L., \& Lenkoski, A. (2011), Robust FDI Determinants: Bayesian Model Averaging in the Presence of Selection Bias, University of Washington, Washington.

Gujarati, Damodar N. (2004). Basic Econometrics $4^{\text {th }}$ Edition. The McGrow-Hill Companies.

Hines, J. R. (1998). International Taxation And Multinational Activity. The University Of Chicago Press Working paper. Chicago and London, 39-72.

Hornberger, Kusi, J. Battat, \& P. Kusek. (2011). Attractive FDI: How Much Does Investment Climate Matter? Viewpoint: Public Policy for the Private Sector, World Bank, Agustus. 
Lipsey, Robert. E. (2001). Foreign Direct Investors in Three Financial Crises. Working Paper 8084. Cambridge: NBER.

Moosa, Imad A. (2002). Foreign Direct Investment: Theory, Evidence, and Practice. New York: Palgrave.

Murthy, K.B. dan Bhasin, N., (2015), The impact of bilateral tax treaties: A multicountry analysis of FDI inflows into India. The Journal of International Trade \& Economic Development, 24(6), pp.751-766.

Nachrowi, D Nachrowi \& Hardius, Usman. (2006). Pendekatan Populer dan Praktis Ekonometrika Untuk Analisis Ekonomi dan Keuangan,Lembaga Penerbit FEUI, Jakarta.

Nurhidayat, R. (2012), Tax Treaty dan Foreign Investment di Indonesia. Finance and Banking Journal Vol. 14 No. 1, June 2012, pp.44-49.

Ohno, Taro. (2010). Emprical Analysis of International Tax Treaties and Foreign Direct Investment, Public Policy Reviews Vol. 6 No.2, March 2010. Policy Research Institute, Ministry of Finance, Japan.

Tambunan, M. R. U. D. (2016). Nilai dari Sebuah Perjanjian Penghindaran Pajak Berganda (P3B) di Negara Berkembang. http://www.ortax.org/ortax/?mod=issue\&page=show\&id=72\&list=\&q=\&hlm =3\#_1ax. Accessed: September 23 ${ }^{\text {th }}, 2017$. 